\author{
Jelena Anđelković* \\ Faculty of Organizational Sciences \\ University of Belgrade, Serbia \\ jelena.plecas@fon.bg.ac.rs

\section{Marija Meršnik} \\ Faculty of Organizational Sciences \\ University of Belgrade, Serbia \\ marija.mersnik@fon.bg.ac.rs

\section{Jovana Jović} \\ Faculty of Organizational Sciences \\ University of Belgrade, Serbia \\ jovana.jovic@fon.bg.ac.rs
}

\title{
PROJECT-BASED TRANSLATION OF WIKIPEDIA ARTICLES IN A TERTIARY ESP CONTEXT: PLANNING, EXECUTION AND LESSONS LEARNT
}

\section{Abstract}

Contemporary ESP instruction tends to avoid traditional teaching methods such as translation, since these were seen as obsolete and believed to discourage communication skills. Attitude towards translation of specialized authentic texts, however, has been changing, mostly because of its potential as an activity that contributes to students' content and language knowledge and transferable skills, such as problem-solving, collaboration, decision-making, etc. Following the constructivism-based learning theories, this article presents the implementation of Project-Based Learning (PBL) in a tertiary ESP context on a collaborative English-Serbian translation and peer review project of selected Wikipedia articles. It outlines the project execution phases and reports on the results of a questionnaire investigating students' evaluation of the project. The results indicate the respondents' overall satisfaction, especially regarding the acquired content knowledge, technical and teamwork skills, and a better grade gained in the course. The results also indicate room for improvement in both the organizational aspects of the project, and collaboration between ESP teachers and project participants, as this may lead to more proficient language competencies.

\section{Key words}

ESP, Wikipedia, project-based learning (PBL), translation, collaboration, social constructivism.

* Corresponding address: Jelena Anđelković, Faculty of Organizational Sciences, University of Belgrade, Jove Ilića 154, 11000 Belgrade, Serbia. 


\section{INTRODUCTION}

The teaching of English for specific purposes (ESP) has been undergoing constant modifications motivated by globalization, technological innovations, the dominant role of English as the international lingua franca, and many other factors. Traditional approaches to language teaching cannot keep track with the fast-paced changes. One of the approaches which emphasizes the social aspect of learning is social constructivism. Social constructivist approaches to ESP teaching challenge ESP teachers to make their teaching learner-centered, empower learner autonomy, and find best modes to incorporate content with language learning, at the same time developing learners' transferable skills. Finally, the question arises whether longabandoned translation activities could be used in an ESP class to this end.

Translation as a method of foreign language teaching has been generally associated with the Grammar Translation approach (Chirobocea, 2018a: 67) and therefore often avoided in recent decades as it was believed to discourage the development of communicative skills. This attitude to translation methods has taken a positive turn at the end of the century, with the Post-communicative cognitive paradigm (Marinov, 2016: 229). Some authors nowadays see translation as a fifth skill, an addition to the primarily communicative skills of reading, speaking, listening, and writing (Chirobocea, 2018a: 71; Janulevičienè \& Kavaliauskienė, 2015: 39; Kavaliauskienè \& Kaminskienė, 2009: 176; Kic-Drgas, 2014: 258; Leonardi, 2009: 142 ), or a skill not separate, but highly dependent on and inclusive of other skills (Leonardi, 2009: 143). Under the post-communicative cognitive paradigm, translation is believed to improve analytical skills and strengthen grammatical competence and performance (Leonardi, 2009: 141).

Recent literature proves that translation-based activities are especially beneficial in the ESP context. Kic-Drgas (2014), for example, suggests new methods for implementing translation into the teaching process as a way to support the multidisciplinary nature of ESP, i.e. its integration of specific content knowledge and language skills. A thematic analysis of academic papers on the use of the translation method in ESP classrooms by Mažeikienè (2018) shows that the use of mother tongue and translation are beneficial for ESP learners as these activities encourage and facilitate comprehension of specialized texts and materials, improve learners' knowledge and understanding of specific subject fields, and teach students to focus on accuracy. Furthermore, translation contributes to learners' analytical skills since it involves problem-solving discussions about encountered difficulties, as explained by Kic-Drgas (2014: 260), develops critical reading skills (Avand, 2009: 45; KicDrgas, 2014: 259), and helps raise students' awareness of both positive and negative transfer, as well as the absence of perfect correspondence between languages (Kavaliauskienė \& Kaminskienè, 2007: 134; Marinov, 2016: 227). It is also seen as an interactive learner-centered activity that promotes learner autonomy (Mahmoud, 2006: 30) as it urges translators to evaluate their existing knowledge, define objectives, and select and critically assess resources. 
As ESP teachers at a business-oriented university, we have decided to reconsider the use of translation as a supplementary teaching method and evaluate the potential benefits it may bring to the students. The following sections will describe a collaborative translation project undertaken as an extension of an ESP course at a faculty at the University of Belgrade, in cooperation with Wikimedia Serbia. The project follows the social constructivist paradigm and employs projectbased language learning (PBLL) to integrate ESP with content and make language learning learner-centered, collaborative, and contextual, resulting in a tangible product. The initial hypothesis of this project was that translation would be a useful tool not only for developing language competencies, expanding the professional vocabulary and contributing to content knowledge of the students, but for improving other transferable skills such as teamwork, time management, organizational skills, etc.

The structure of this paper is as follows: following the Introduction, section 2 places the project in a theoretical perspective by providing a literature review on constructivism, social constructivism, project-based learning (PBL), and its applications and benefits for the educational context. Section 3 outlines examples of Wikipedia being used as a collaborative teaching tool in a language-learning context, especially for translation. Section 4 provides information on the conception, planning and execution of our translation project, followed by project evaluation using questionnaire results (section 5) and discussion (section 6). The final section (section 7) offers conclusions and suggestions for further research.

\section{LITERATURE REVIEW}

Constructivism is one of the leading theoretical positions in education that represents a significant shift in the understanding of human learning and the conditions that best promote it (Amineh \& Asl, 2015:10). Summaries by Hoover (1996) and Twomey Fosnot (1989), Hein (1991: 1-12) and Kiraly (2005, 2012) provide an outline of the shared principles of constructivist-based learning theories:

- Learning happens when a learner constructs new understandings using current knowledge.

- Learning is not a passive, but rather an active process; it happens through rethinking and adapting old ideas.

- Learner-centered instructional methods are at the focus of this approach learners are encouraged to work independently, autonomously, responsibly, and be actively involved in the construction of knowledge. Teachers facilitate learning by supporting learners in the learning process, promoting their motivation and critical thinking.

Social constructivists share the common set of constructivist principles above, but also believe in the social nature of learning: knowledge as a human product is 
socially and culturally, rather than individually constructed (Ernest, 1999: 4-5; Prawat \& Floden, 1994: 37), and learning occurs only when learners interact and collaborate with others. In addition, learning can only take place in the zone of proximal development, "the distance between the actual developmental level as determined by independent problem-solving and the level of potential development as determined through problem-solving under adult or in collaboration with more capable peers" (Vygotsky, 1978: 86). Therefore, instructional approaches such as reciprocal teaching, peer collaboration, cognitive apprenticeships, problem-based instruction, and others involve collaboration among learners (Amineh \& Asl, 2015: 14).

Another social constructivism-based collaborative and cooperative learning approach is Project-based Learning (PBL). PBL employs complex tasks on solving challenging questions or problems, investigating, and making decisions. This approach involves students in a number of interdisciplinary and student-centered activities that require critical thinking, problem solving, creativity, collaboration, communication, etc. A project should have a realistic and explicit learning goal and a tangible final product (Stoller, 2006: 109), such as an oral presentation, bulletin board display, or some other publicly-exhibited output (Poonpon, 2017: 2).

PBL has certain similarities with other constructivism-based instructional approaches, such as problem-based learning (Helle, Tynjälä, \& Olkinuora, 2006: 294-297), experiential and collaborative learning, and content-based instruction (CBI). The main difference between project- and problem-based learning is the focus problem-based learning focuses on the process, while PBL focuses on the end product. PBL has some elements of collaborative learning (as all participants need to contribute to the common goal) and experiential learning (since PBL asks for active reflection and conscious engagement rather than passive experiences, according to Kokotsaki, Menzies, and Wiggins (2016: 2). The main similarity between CBI and PBL is that they are both learner-centered and incorporate language learning with content knowledge acquisition.

Being student-centered, PBL makes teachers facilitators rather than instructors. The success of PBL in the classroom lies in the teacher's ability to guide, direct, and assess students' learning (Vân Khánh, 2015: 229-230) and effectively motivate, support, and guide them along the way. Helle, Tynjälä, and Olkinuora (2006) point to the importance of teachers leaving the room for learners to control the learning process, as this will help students learn how to be self-reliant (Kokotsaki et al., 2016: 268). PBL enhances students' motivation in several ways: they are faced with real world tasks and explicit learning goals (Bell, 2010: 42), they are empowered to take charge of their own learning, and have an active part in evaluating their projects and those of their peers (Foss et al., 2008).

PBL is a flexible instructional approach that can be implemented in various educational contexts, including language learning. Project-based Language Learning (PBLL) has been explored by a number of authors (Beckett, 2006; Beckett \& Slater, 2005; Gibbes \& Carson, 2014; González-Davies, 2017, etc.). One of the main strengths of PBLL is that it develops communicative competence through the use of 
authentic language (Fried-Booth, 1982), as well as non-linguistic skills in research and collaborative work (Moulton \& Holmes, 2000). Project work is believed to result not only in simultaneously improving students' language skills and content knowledge (Beckett, 2002: 62), but also in building learners' confidence, self-esteem, autonomy, and cognitive abilities (Simpson, 2011: 50-71; Stoller 2002: 110). However, the implementation of PBLL requires a relatively high foreign language proficiency (Gibbes \& Carson, 2014), but this can be an opportunity rather than a limitation, since students may be motivated by being faced with teaching materials of a slightly higher proficiency level (Vân Khánh, 2015: 230).

A significant amount of research is dedicated to the application of PBL in the tertiary ESP context (for example, Alsamani \& Daif-Allah, 2016; Díaz Ramírez, 2014; Foss et al., 2008; Simpson, 2011; Vân Khánh, 2015, etc.). However, no reports of comprehensive translation projects being conducted in university ESP classes have been found in the available literature. Instead, such projects have been applied in the teaching of translation as a vocational skill with the purpose of exposing future translators to authentic work settings and enabling them to develop not only degree-specific, but also other transferable competencies (Galán-Mañas, 2011; Kiraly, 2005, 2012).

In ESP, translation of specialized texts has been used as an aid or a supplementary activity (Kavaliauskienė \& Kaminskienė, 2007: 133), aimed at improving language learning (Kavaliauskienė \& Kaminskienė, 2007), or teaching terminology (Koteva, 2020; Laviosa \& Cleverton, 2006). For example, Laviosa and Cleverton (2006) report on a method they developed in teaching tourism students translation with a focus on specialized vocabulary and culture-bound words, stating that at the end of the designed course their students were able "to reflect on lexicogrammatical mismatches between the source and target language and propose wellreasoned translation solutions" (Laviosa \& Cleverton, 2006: 11). Surveys have been conducted among ESP students to identify their views of the relevance of translation of professional and/or scientific terms into Serbian (Stojković, 2021), as well as assess the use of translation activities as language learning devices, reporting positive feedback and confirming they helped students with specialized vocabulary (Chirobocea, 2018b).

\section{WIKIPEDIA AS A TEACHING TOOL}

Wikipedia (www.wikipedia.org) is a multilingual open encyclopedia and one of the most popular websites in the world, with articles in 309 world languages and over 6 million articles in English alone. ${ }^{1}$ Wikipedia has been completely communitydriven (McDonough Dolmaya, 2014), i.e. created through collaborative work of volunteers: anyone can contribute, either by adding articles, deleting or editing

\footnotetext{
${ }^{1}$ https://meta.wikimedia.org/wiki/List_of_Wikipedias\#Grand_Total
} 
them, adding references or multimedia, translating articles of their own choice from another language or suggesting articles for translation (Lerga \& Aibar, 2015: 12; McDonough Dolmaya, 2017: 148). The translation model employed is collaborative translation $^{2}$ : online translation generated by volunteer Internet users who collaborate on translation projects without any (or with little) financial reward, usually for and at the request of an organization (Cronin, 2012: 4).

Wikipedia is a very popular knowledge source among university students. Although teachers are usually skeptical about the quality and legitimacy of using Wikipedia as a form of reference because of its unclear authorship, anonymous edits, and the absence of formal peer review process (as reported by Knight \& Pryke, 2012: 651), students value it as a source of reference for various assignments (Brox, 2012; Knight \& Pryke, 2012: 656-657) because of the easy access to information, facilitated navigation through hyperlinks, etc. (Lim, 2009: 2193-2194).

Despite skepticism about using Wikipedia as a source of information, it has often been used as a teaching tool. Because of its interdisciplinary nature, Wikipedia is suitable for collaborative work and authentic project-based tasks (Martínez Carrasco, 2018: 909), and is believed to bring many educational benefits, such as strengthening interaction, communication, comprehension, research, social and other skills (Lerga \& Aibar, 2015: 7-8). This makes it particularly valuable in academic writing and foreign language learning.

There are only several examples of Wikipedia articles being used for collaborative translation projects, and they are mostly carried out with university students specializing in translation, while their implementation in a tertiary ESP context is largely missing. Brunette and Gagnon (2013), for example, report on using already translated Wikipedia articles at the University of Quebec in Outaouais (UQO), Canada, as a tool for their students to practice English-French translation revision and review. A project similar to the one described in this paper and placed in the same constructivist framework is presented by Martínez Carrasco (2018), who reported on the use of Wikipedia articles in teaching translation to bachelor degree students in Translation and Interpreting at Jaume I University, in cooperation with Wikipedia Spain, with the purpose of developing their comprehensive translation competencies (Martínez Carrasco, 2018: 913). The project was part of a larger international network called "Teaching Translation via Wikipedia" that focused on "authentic project-based methodology and collaborative work in the translation classroom" (Martínez Carrasco, 2018: 912) and included participants from Spain, Argentina, Jordan, Turkey, and other countries. Another similar project was implemented at the Department of Translation of the University of Gdańsk, Poland for three years in a row (2010-2013), with students working on their translation competencies while at the same time expanding the Polish Wikipedia content and

\footnotetext{
${ }^{2}$ Collaboration is inevitable in all translation projects and may occur between any of the following: authors, publishers, translators, translating agencies, two or more translators working on the same text (O’Brien, 2011: 17).
} 
acquiring experience as Wikipedia editors. ${ }^{3}$ Al-Shehari (2017) reports on translating Wikipedia entries from English into Arabic with postgraduate students of translation at Durham University as a means of creating a more engaging, competitive and motivating environment for teaching translation. No evidence was found on a similar project being carried out in an ESP context.

\section{PROJECT OUTLINE}

At the faculty in question, ESP is taught in two mandatory (ESP1 and ESP2) and one elective course (ESP3). English for Specific Purposes 1 (ESP1) is a $1^{\text {st }}$ year twosemester course introducing students to language structures and core terminology typical of English for business, management, and information technologies, and the basics of business correspondence. English for Specific Purposes 2 (ESP2), taught during the two semesters of the second year, focuses on more specific English terminology and more complex language structures characteristic of the students' study programs. The mandatory ESP1 and ESP2 are large and mixed ability classes (approximately 800-900 students enroll in each of these courses every academic year). Large heterogeneous groups, combined with traditional teaching methods, lead to a gradual drop in student engagement, motivation, and attendance rate as the course progresses. This made us reconsider our current teaching practices and introduce some innovations, such as mobile-friendly web apps for vocabulary teaching and revision (Nikolić, Anđelković, \& Abramović, 2020), and a collaborative translation project to be presented in this paper.

The project in question was initiated by the representatives of Wikimedia Serbia (students attending the ESP2 course at the time) and the faculty's ESP lecturers. Wikimedia Serbia is part of the Wikipedia Education Program ${ }^{4}$ and their representatives saw an opportunity to expand and enrich the Serbian Wikipedia by offering collaboration within the ESP2 course, giving the students an opportunity for collaborative learning in an innovative environment.

The first cycle of the project was conducted during the academic year $2017 / 2018$, followed by iteration in the academic year 2018/2019. The stages of the project correspond to those outlined in Fragoulis and Tsiplakides (2009) and include: (a) project conception and planning, (b) project execution, and (c) project evaluation.

\subsection{Project conception and planning}

Upon initial agreement on further collaboration, Wikimedia representatives and ESP lecturers agreed on several aspects crucial for further project planning:

\footnotetext{
${ }^{3} \mathrm{https} / /$ wikimania2013.wikimedia.org/wiki/Submissions/Wikipedia_in_teaching_translation_at_the_university_level

${ }^{4}$ https://en.wikipedia.org/wiki/Wikipedia:Education_program
} 
- optimal number of students;

- number, length, and language level of Wikipedia articles to be translated from English into Serbian;

- rewards;

- training; and

- project execution elements and timeline.

Considering the available human resources, time allotted for the activity, and due dates for project completion, the first iteration of the project included a total of 106 students working on 65 articles, either individually or in groups of up to four students per article. The students could be awarded up to 5 bonus points (in addition to the maximum of 100 points available in the ESP2 course). Since the project participation required specific digital skills, Wikimedia representatives awarded up to 2 points and the ESP team awarded up to 3 points. Articles were selected by taking into account the following criteria:

a) topic is related to the students' field of studies;

b) students had already gained some knowledge about the respective topics in their subject-specific university courses;

c) articles are of similar difficulty in terms of English language proficiency.

The subsequent iteration of the project (academic year 2018/2019) included 150 students working on the translation and revision of 29 Wikipedia articles. The students were to be awarded a bonus of up to 10 (for translation) or up to 5 points (for revision) in addition to the total of 100 points in the course. This time, $4 / 10$, and $2 / 5$ points were awarded by Wikimedia representatives for the technical aspects of the submitted text, while the remaining points were assigned by the ESP teachers. An additional criterion for the selection of articles was that they were of adequate length so that each translator got an average of 4,500 characters (with spaces) and each reviewer got twice as much.

Prior to translation and revision work, the participants were to attend a mandatory technical training (first project iteration) and both technical and translation training (second project iteration). After the training, the project was executed as follows:

a) translation of articles;

b) teachers' feedback on translations submitted;

c) revision of translated articles;

d) final revision of translated and revised articles and feedback by ESP teachers.

Each step of project execution is described in more detail in the following sections. 


\subsection{Project execution}

In the first iteration, the students applied for project participation via Google Forms provided by the Wikimedia representatives. In the second year, they used the same mode of application, but additionally opted for translation or revision. After the application was closed, students were accepted on a "first come first served" basis. The selected students chose an article they wished to translate/revise. Depending on its length, each article was awarded a team of between two and four collaborators for translation (hereafter referred to as translators), and at least one collaborator for revision (hereafter referred to as reviewers). As mentioned previously, in the first year of project implementation, there were instances of individual students working on an article.

\subsubsection{Training}

Before collaborative translation and revision tasks, all selected participants had to attend a mandatory two-hour training. The first cycle of the project included only the technical training, with Wikimedia representatives introducing students to the technical aspects of editing a Wikipedia article, e.g. using Wikipedia tools for creating hyperlinks, properly inserting references, dividing text into paragraphs, inserting images, etc.

In the second cycle of the project, the training also included an outline of translation and revision principles. The purpose of this training provided by ESP teachers was to help students develop basic translation skills and competencies. Even though employing translation as a method does not require ESP learners to have an in-depth knowledge of translation theory and high competence in translation (Mažeikienè, 2018), it was believed that the introduction of basic principles and guidelines would improve the collaborative translation process and the quality of translated content, and significantly reduce the time teachers spent on post-reviewing. The decision was also based on experience gained from the first iteration of the project, when students submitted poorly translated texts and exhibited a significant lack of language skills and profession-specific terminology knowledge in their native language. The lack of Serbian terminology equivalents is attributed to the heavy influence of the English language on the fields they study in, which often leads to students uncritically transferring English terms or using several terminological variants in the same text (Anđelković, 2018).

The second part of the training was introduced to encourage students to divide the translation process into the following steps:

1. Close reading of the article for translation (hereafter referred to as the source text - ST), as this can aid comprehension and reduce misunderstandings; 
2. Compilation of a terminology list; unification of terminology translation among the collaborators to ensure harmonized terminology throughout the translation;

3. Division of the ST into parts for each collaborator to translate individually;

4. Preparing a draft translation by each collaborator;

5. Collaborative work on the first draft of the translation, aimed at checking it for errors, discovering and solving transfer problems, unifying terminology, correcting mistranslations, checking for omissions, and quality control in general;

6. Submission of the translated article to ESP teachers for grading and feedback;

7. Revision of translated articles by revision teams, correcting typographical errors, grammar, style, structure, unidiomatic language, or content;

8. Reviewers were advised to revise the translated text both unilingually (by looking at the target text - TT only) and bilingually, with referring back to the ST.

9. Submission of the revised article to ESP teachers for grading and feedback.

\subsubsection{Collaborative translation and revision}

After the training sessions, the translation teams had 10 days to complete the translations. The teams were strongly advised to follow the guidelines provided during the training, to divide the article equally among team members and, once each translator had completed their part, to revise the whole article collaboratively to ensure the quality of the translated text. The teams were encouraged to contact ESP teachers or Wikipedia representatives for scaffolding advice if they encountered a technical/translation problem. To further encourage collaboration, all team members were awarded the same number of points for the task, regardless of individual contribution.

After the deadline, the submitted translations were graded by the ESP teachers within the two subsequent weeks. This was done using Diigo, ${ }^{5}$ an online extension for annotating, archiving and bookmarking web pages that enabled the ESP teachers to make changes, highlight, comment, and share their feedback. Each team was awarded the allotted number of points, but no further changes to the translated text were required from the translators.

In the second year of the project (which included the reviewing aspect), the articles were sent to revision teams to make necessary alterations within five days. The revision teams were required to make changes directly on the Wikipedia platform and were not familiar with the comments ESP teachers previously made. Reviewers were also obliged to provide a brief summary justifying the corrections (approximately 100 words) as this served as proof that the article in question had actually been revised. After the deadline, ESP teachers had a week to revise the

\footnotetext{
${ }^{5}$ https://www.diigo.com/
} 
articles again, compare them to the translated ones, comment on the quality of revision using Diigo extension, and award points for revision.

\section{PROJECT EVALUATION}

In the first year of the project there was no official project evaluation. However, ESP teachers gained significant insight through student feedback in class after the project was completed and decided to conduct a survey in the second year. After the collaborative translation and revision was finalized, a questionnaire (see the Appendix) was administered to all participants to survey their satisfaction with the project conception, planning, execution, and outcomes. The questionnaire was constructed following the guidelines outlined in Dörnyei (2003), was fully anonymous and consisted of 11 questions divided into three sections.

The first section contained general questions regarding the respondents' gender (Q1), study program $(\mathrm{Q} 2)$, grade point average $(\mathrm{Q} 3)$, grades earned in the two ESP courses (Q4-Q5), whether they participated in the project as translators or reviewers (Q6), and how many participants there were on their team (Q7). The second section focused on project implementation and the participants' satisfaction with the project, usefulness of the training, cooperation between team members, etc. (Q8). The third section dealt with project outcomes and benefits (Q9-Q10). The final, open-ended question (Q11), allowed participants to add comments and suggestions.

\subsection{Section 1: General information}

A total of 66 students (out of 150 project participants) completed the questionnaire, making the response rate $44 \%$. The respondents were predominantly female $(47$, or $71.2 \%)$. The GPA of more than a half of the respondents (35, or 53\%) was between 8.00 and 8.99/10.00. Respondents were generally more successful in their ESP2 than in ESP1 exam, as almost a half of the respondents (47\%) received the highest grade in ESP2 (as compared to ESP1 where 31.8\% earned the highest grade).

Only 11 respondents (16.7\%) said they worked on the project as reviewers, while the rest were translators $(55$, or $83.3 \%)$. The size of translation/revision teams was relatively evenly distributed (Q7): one third of the respondents (22, or $33.3 \%$ ) worked in groups of three, a slightly smaller number worked in groups of two (17, or $25.8 \%$ ), groups of four or individually (11 respondents, or $16.7 \%$ ).

\subsection{Section 2: Project work}

The second section of the questionnaire (Q8) consisted of a cluster of nine statements focusing on project execution. The respondents were asked to rate (on a 
6-point Likert scale) the following aspects of the project: the length and the complexity of the articles for translation/revision, the usefulness of training guidelines, the helpfulness of ESP teachers and Wikipedia representatives, the collaboration among team members, the number of points awarded for their effort, and their readiness to recommend the project to their colleagues.

The distribution of respondents' answers to most statements regarding project execution was quite diversified. Namely, while the majority of respondents either agreed (24, or $36.4 \%)$ or completely agreed (15, or $22.7 \%)$ that the text was of adequate complexity, almost a fourth $(16$, or $24.2 \%)$ was indecisive. Similarly, while the majority of respondents believed that the translation guidelines were helpful $(19$, or $28.8 \%$, of them agreed, and 11 , or $16.6 \%$, completely agreed with this statement), an equal number (11 respondents, or 16.6\%) was either doubtful or believed the guidelines were not useful. Next, the respondents' opinion regarding the satisfaction with the number of points awarded for participation in the project was almost uniformly distributed between "I completely agree" and "I completely disagree". Another interesting result is that an almost equal number of students agreed (13 of them, or $19.7 \%$ ) and disagreed (12, or $18.2 \%)$ that the ESP teachers' feedback was useful.

The majority of students, however, were completely satisfied with the amount of text they received for translation/revision (25, or $37.8 \%$ ), the usefulness of technical guidelines $(24$, or $36.4 \%)$, and the collaboration with other team members (26 respondents, or almost 40\%). In response to statements regarding the helpfulness of ESP teachers and Wikimedia representatives, the majority of the respondents marked N/A, presumably because they needed no help. Finally, the majority of respondents (29 out of 66 , or close to $44 \%$ ) marked that they would recommend their colleagues to apply for this project, which points to the whole project as a generally positive experience.

\subsection{Section 2: Project outcomes}

The last section of the questionnaire focused on the benefits of project participation. In response to Q9, 39 respondents (59\%) marked new knowledge, improved skills, and a higher grade in ESP2 course as the most important benefits. Thirteen respondents (19.7\%) claimed that it had helped them improve teamwork skills. Eleven respondents (16.7\%), however, believed they had not benefited from this project in any way.

Q10 referred to additional and more specific language benefits resulting from the project and comprised a cluster of four statements to be rated on a 6-point Likert scale. The distribution of respondents' reactions to these statements was quite diversified. For example, almost a third (21 out of 66 respondents, or $31.8 \%$ ) agreed that the project participation had a positive influence on their proficiency in English for specific purposes and the knowledge of technical terminology, while a similar 
number (18 respondents, or 27.3\%) was unsure of its influence. The results regarding the positive influence of the project on the awareness of the gaps that the respondents may have in the knowledge of their mother tongue came as a surprise, as almost half of them (32, or 48.5\%) either disagreed or completely disagreed with this statement. Responses to the statement regarding ESP teachers' feedback clearly indicate that the respondents were not satisfied as 26 of them (31.8\%) completely agreed and 21 (31.8\%) agreed that a more specific response should be provided regarding the mistakes made in translation/revision. However, the majority agrees $(24$, or $36.4 \%)$ or completely agrees $(19$, or $28.8 \%)$ that collaborative tasks such as this one contribute to better acquisition of domain-specific knowledge.

In answer to the last question, the respondents left 11 comments which mostly concentrated on the technical and organizational aspects of the project. Some issues were raised regarding the overall lack of feedback or the lack of individualized or detailed feedback. The respondents mostly complained about the evaluation system and claimed that the number of points awarded was disproportionate to the effort invested in the task. This is especially true regarding the revision part which, as several respondents asserted, can be even more difficult and demanding than translation, especially when the translation itself has been done poorly. Three respondents disliked the fact that their translations were edited by third parties (Wikimedia administrators) while they were still working on them, which resulted in ambiguities, mostly in the use of several term variants for the same concept, and consequently, fewer points for student teams. Other objections referred to the fairness of the selection process, as some respondents believed that students who attended classes regularly or the ones with lower level of English should be given advantage.

\subsection{Section 2: Project evaluation results analysis}

The project evaluation survey helped identify both benefits and drawbacks of the collaborative translation project. Although evaluation was conducted in the second year of project implementation, with prior adjustments made to the first iteration of the project, it showed that there was still room for further improvement.

Responses point to certain benefits that the project brought to its student participants, which may further imply that it should be extended with future generations. As regards the project planning and execution, the respondents were generally satisfied with the selection and length of articles for translation and revision, collaboration within their translation/revision teams, and technical support provided by Wikimedia Serbia. The majority of respondents also believed that the project brought them certain benefits: they obtained a higher grade in ESP2 course, improved their skills and knowledge in the respective subject fields, and would thus recommend their colleagues to participate in this project. 
Certain adjustments and alterations to project planning and implementation are necessary, especially with the technical and organizational aspects, such as the respondents' dissatisfaction with the "first-come first-served" principle in candidate selection, without giving advantage to weaker students or the ones attending classes regularly. The respondents were even more dissatisfied with the evaluation and grading system, the fact that translation and revision were valued differently, equal number of points for all team members regardless of individual effort invested, and alterations made by third parties while the project was still ongoing. As these matters may greatly affect student motivation, they need to be dealt with in the future.

What needs to be addressed most are the respondents' remarks regarding their collaboration with ESP teachers and the benefits of translation tasks to their language skills. The responses indicate that the translation and revision guidelines need to be improved, and that the respondents expect more specific and individualized feedback. In addition, the respondents were not completely convinced that the project helped them improve their knowledge of technical terminology in English, nor were they absolutely sure that it pointed to the gaps in the knowledge of their own mother tongue.

\section{DISCUSSION}

To the best of our knowledge, there are no instances of comprehensive translation projects similar to this one conducted in the context of teaching ESP at a tertiary level. Instead, such projects have been a part of translation study programs and involved students who are preparing for a career in translating and interpreting (e.g. Al-Shehari, 2017; Brunette \& Gagnon, 2013; Martínez Carrasco, 2018). Projects conducted in the two contexts (the tertiary ESP context and translator training context) belong to the same social constructivist paradigm, share some common aims (such as empowering students, putting them in charge of their own learning, encouraging collaboration and teamwork, etc.), and are similarly conceptualized and executed (see, for example, Martínez Carrasco, 2018).

However, the fact that the context of the project execution and its participants differ, also leads to the difference in motivation and perceived benefits of project participation. Namely, while the participants of the project presented here are $2^{\text {nd }}$ year undergraduates of non-linguistic orientation, with uneven English language skills (reflected in the grade awarded for ESP courses) with no or very little translation experience, the participants of other similar projects (presented in AlShehari, 2017; Brunette \& Gagnon, 2013; Martínez Carrasco, 2018) are at least $3^{\text {rd }}$ and $4^{\text {th }}$ year undergraduate or postgraduate translation students who are already familiar with relevant translation strategies and resources (Martínez Carrasco, 2018: 913) and aim at developing even more comprehensive degree-specific translation and other transferable competencies (Galán-Mañas, 2011; Kiraly, 2005, 2012). 
The two groups of participants are not expected to be motivated in the same way, nor to share a common set of project expectations. For example, Al-Shehari (2017: 369-371) reports that the motivation of his postgraduate translation students to participate in the English-Arabic Wikipedia translation project went beyond that of merely receiving a grade; they were also motivated by being able to choose texts for translation autonomously, and by the prospect of their work eventually being published and more widely visible. For ESP students participating in the translation project presented here, on the other hand, a higher grade (rather than visibility and autonomy) seemed to be one of the greatest perceived benefits, while some of the major students' concerns were the objectivity and fairness of the evaluation, as well as the technical aspects of the project, such as grading system and participant selection (see section 5 for more detail).

By comparing the expectations of ESP students and translation students participating in similar translation projects, more conclusions can be drawn and alterations made to improve the overall satisfaction with the future iterations of our ESP translation and peer review project.

Even though extensive PBL-based projects are largely missing from the tertiary ESP context, translation activities have been frequently used as a supplementary activity (Kavaliauskienè \& Kaminskienè, 2007; Kic-Drgas, 2014; Laviosa \& Cleverton, 2006; Mažeikienè, 2018), but with a slightly different focus than in the translation training context. More specifically, authors dealing with LSP largely emphasize the usefulness of translation activities for teaching and learning specialized vocabulary and culture-bound words (Chirobocea, 2018b; Laviosa \& Cleverton, 2006; Leonardi, 2009: 148-150; Stojković, 2021). Chirobocea (2018b: 72-73) points to a number of benefits of terminology lists or glossaries for ESP students; for example, it helps them not only learn and consolidate terminology and content knowledge, but also identify false friends, synonymy, homonymy, polysemy, positive and negative transfer related to prefixes, suffixes or specific phraseology (Chirobocea, 2018b: 72). The positive feedback on the relevance of translation for ESP students, especially for the teaching of terminology, has been confirmed through surveys (Chirobocea, 2018b; Stojković, 2021). The project presented in this paper, however, has not put sufficient emphasis on the terminology aspect of translation activities, which is another adjustment to be implemented in the future iterations of the project.

\section{CONCLUSION AND IMPLICATIONS FOR FURTHER RESEARCH}

Generally speaking, we believe that the two iterations of the collaborative translation and revision project were beneficial to its participants. Students were presented with an authentic task that combined content and language learning, empowered them to take charge of their learning by choosing an article of interest to translate or revise, and offered training and scaffolded instruction for successful task completion. Along with the additional points for participating in the project, the 
students worked on their language competencies, both English and Serbian (e.g. by solving terminology gaps and inconsistencies), and are believed to have improved their content knowledge, developed teamwork and collaboration, critical thinking, decision-making, time management, etc.

We believe that the project was not valuable for its participants only, but to the wider audience as well. The result of this project work, a Serbian translation of a Wikipedia article, is a publicly available and tangible product that expands the freeof-charge collaborative knowledge that Wikipedia offers to the world.

As Beckett (2002) and Beckett and Slater (2005) report, students and teachers sometimes disagree on the benefits of a project, as also indicated by some of the responses to the project evaluation survey. For further success of the project, certain alterations in line with survey responses and findings of other authors need to be made. Firstly, the number of participants in the project needs to be reconsidered and potentially reduced, as this would enable better collaboration between ESP teachers and student teams, and allow for a more detailed and more frequent teacher feedback. Secondly, translation guidelines need to be further adapted to student needs so that future translation workshops would be more useful and include more hands-on translation work to be done collaboratively, not only with the purpose of indicating common translation and editing mistakes, but also helping students understand the translation process and the importance of careful reading and reflecting on the text prior to actually translating it (Kic-Drgas, 2014: 259). Thirdly, the project implementation may include some additional tasks, such as submitting a bilingual terminology list or a glossary with term definitions prior to translating the text itself. The creation of a glossary is expected not only to draw students' attention to the importance of using consistent terminology, but also to help them become aware of terminology gaps and inconsistencies, and potentially even expand their knowledge of the subject matter. Fourthly, the problem with deficient feedback could be solved in several ways: by reducing the number of participants (as suggested earlier); by tracking students' progress more frequently by means of formative evaluation throughout the project execution; or by introducing additional peer feedback on translation. Namely, as proposed by Martínez Carrasco (2018: 914), revision teams could recommend changes that translation teams can either accept or reject, while additional time could also be allocated to individual and peer feedback sessions to discuss their performance and the difficulties encountered during the project (as also suggested by Kic-Drgas, 2014: 260). We believe that this would indirectly contribute to students' feeling of achievement in terms of improved language skills and knowledge of professional terminology. Lastly, some technical and organizational issues identified in the survey, such as the criteria for choosing project participants or alterations to Wikipedia articles made by third parties while the project is ongoing, cannot be easily altered for practical reasons, or need to be addressed by Wikimedia representatives.

[Paper submitted $24 \mathrm{Feb} 2021]$

[Revised version received 19 May 2021]

[Revised version accepted for publication 30 Sep 2021] 


\section{References}

Alsamani, A. A. S., \& Daif-Allah, A. S. (2016). Introducing project-based instruction in the Saudi ESP classroom: A study in Qassim University. English Language Teaching, 9(1), 51-64. Retrieved from https://files.eric.ed.gov/fulltext/EJ1087117.pdf

Al-Shehari, K. (2017). Collaborative learning: Trainee translators tasked to translate Wikipedia entries from English into Arabic. The Interpreter and Translator Trainer, 11(4), 357-372. https://doi.org/10.1080/1750399X.2017.1359755

Amineh, R. J., \& Asl, H. D. (2015). Review of constructivism and social constructivism. Journal of Social Sciences, Literature and Languages, 1(1), 9-16. Retrieved from http://www.blue-ap.org/j/List/4/iss/volume\%201\%20(2015)/issue\%2001/2.pdf

Anđelković, J. (2018). Terminologija menadžmenta: u prilog razvoju terminološke i jezičke politike i planiranja [Terminology of management: A contribution to the development of terminology and language policy and planning] (Unpublished doctoral dissertation). Faculty of Philology, University of Belgrade, Belgrade, Serbia.

Avand, A. Q. (2009). Using translation and reading comprehension of ESP learners. The Asian ESP Journal, 5(1), 44-60. Retrieved from http://asian-esp-journal.com/wpcontent/uploads/2016/01/AESP-Volume-5-Issue-1-May-2009.pdf\#page=44

Beckett, G. (2002). Teacher and student evaluations of project-based instruction. TESL Canada Journal, 19(2), 52-66. https://doi.org/10.18806/tesl.v19i2.929

Beckett, G. H. (2006). Project-based second and foreign language education. In G. H. Beckett, \& P. Miller (Eds.), Project-based second and foreign language education: Past, present, and future (pp. 1-15). Information Age Publishing.

Beckett, G. H., \& Slater, T. (2005). The project framework: A tool for language, content, and skills integration. ELT Journal, 59(2), 108-116. https://doi.org/10.1093/eltj/cci024

Bell, S. (2010). Project-based learning for the 21st century: Skills for the future. The Clearing House: A Journal of Educational Strategies, Issues and Ideas, 83(2), 39-43. https://doi.org/10.1080/00098650903505415

Brox, H. (2012). The elephant in the room: A place for Wikipedia in higher education? Nordlit, 30, 143-155. https://doi.org/10.7557/13.2377

Brunette, L., \& Gagnon, C. (2013). Enseigner la révision à l'ère des wikis: là où l'on trouve la technologie alors qu'on ne l'attendait plus [Teaching revision in the age of Wikis: Where technology is found when it was never expected]. Journal of Specialised Translation, 19, 96-121. Retrieved from https://jostrans.org/issue19/art_brunette_gagnon.pdf

Chirobocea, 0. (2018a). A case for the use of translation in ESP classes. Journal of Languages for Specific Purposes, 5, 67-76. Retrieved from http://jlsp.steconomiceuoradea.ro/archives/005/JLSP5_March2018.pdf\#page $=67$

Chirobocea, 0. (2018b). Translation as language learning technique and the use of L1 in ESP classes: Learners' perceptions. "Ovidius" University Annals, Economic Sciences Series, XVIII(2), 221-227. Retrieved from https://stec.univ-ovidius.ro/html/anale/RO/wpcontent/uploads/2019/02/6-2.pdf

Cronin, M. (2012). Translation in the digital age. Routledge. https://doi.org/10.4324/9780203073599

Díaz Ramírez, M. I. (2014). Developing learner autonomy through project work in an ESP class. How Journal, 21(2), 54-73. http://dx.doi.org/10.19183/how.21.2.4

Dörnyei, Z. (2003). Questionnaires in second language research: Construction, administration, and processing. Lawrence Erlbaum Association. 
Ernest, P. (1999). Social constructivism as a philosophy of mathematics: Radical constructivism rehabilitated? Retrieved from https://systemika.gi.cz/record/1595/files/Ernest,\%20Paul\%20-

\%20Social\%20Constructivism\%20as\%20Philosophy\%20of\%20Mathematics.pdf

Foss, P., Carney, N., McDonald, K., \& Rooks, M. (2007). Project-based learning activities for short-term intensive English programs. Asian EFL Journal, 23(2), 1-19. Retrieved from http://www.asian-efl-journal.com/pta_Oct_07_pf.pdf

Fragoulis, I., \& Tsiplakides, I. (2009). Project-based learning in the teaching of English as a foreign language in Greek primary schools: From theory to practice. English Language Teaching, 2(3), 113-119. Retrieved from https://files.eric.ed.gov/fulltext/EJ1083088.pdf

Fried-Booth, D. (1982). Project work with advanced classes. ELT Journal, 36(2), 98-103. https://doi.org/10.1093/elt/36.2.98

Galán-Mañas, A. (2011). Translating authentic technical documents in specialised translation classes. The Journal of Specialised Translation, 16(1), 109-125. Retrieved from https://www.jostrans.org/issue16/art_manas.pdf

Gibbes, M., \& Carson, L. (2014). Project-based language learning: An activity theory analysis. Innovation in Language Learning and Teaching,8(2), 171-189. https://doi.org/10.1080/17501229.2013.793689

González-Davies, M. (2017). The use of translation in an integrated plurilingual approach to language learning: Teacher strategies and best practices. Journal of Spanish Language Teaching, 4(2), 124-135. https://doi.org/10.1080/23247797.2017.1407168

Hein, G. E. (1991, October). Constructivist learning theory. Paper presented at the CECA (International Committee of Museum Educators) Conference, Jerusalem, Israel. Retrieved from http://www.exploratorium.edu/ifi/resources/constructivistlearning.html

Helle, L., Tynjälä, P., \& Olkinuora, E. (2006). Project-based learning in post-secondary education: Theory, practice and rubber sling shots. Higher Education, 51(2), 287-314. Retrieved from https://link.springer.com/article/10.1007/s10734-004-6386-5

Hoover, W. A. (1996). The practice implications of constructivism. SEDL Letter, 9(3), 1-2.

Janulevičienè, V., \& Kavaliauskienė, G. (2015). ESP students' self-evaluation and attitude towards translation. Journal of Language and Literature, 6(2), 38-43. Retrieved from https://www.researchgate.net/publication/283862774_ESP_students\%27_selfevaluation_and_attitude_towards_translation

Kavaliauskienė, G., \& Kaminskienè, L. (2007). Translation as a learning tool in English for specific purposes. Kalbotyra, 57(3), 132-139.

Retrieved from https://www.ceeol.com/search/article-detail?id=255225

Kavaliauskienė, G., \& Kaminskienė, L. (2009). Proficiency in reading, writing and translation skills: ESP aspect. Vertimo studijos, 2, 171-184. Retrieved from https://www.ceeol.com/search/article-detail?id=681394

Kiraly, D. (2005). Project-based learning: A case for situated translation. Meta: Journal des traducteurs/Meta: Translators'Journal, 50(4), 1098-1111. https://doi.org/10.7202/012063ar

Kiraly, D. (2012). Growing a project-based translation pedagogy: A fractal perspective. Meta: Journal des traducteurs/Meta: Translators' Journal, 57(1), 82-95. https://doi.org/10.7202/1012742ar

Knight, C., \& Pryke, S. (2012). Wikipedia and the university: A case study. Teaching in Higher Education, 17(6), 649-659. https://doi.org/10.1080/13562517.2012.666734

Kokotsaki, D., Menzies, V., \& Wiggins, A. (2016). Project-based learning: A review of the literature. Improving Schools, 19(3), 267-277. https://doi.org/10.1177/1365480216659733 
Koteva, G. (2020). Mastering terminology through translation in English for specific purposes classroom. Science, Engineering \& Education, 5(1), 64-72. Retrieved from https://dl.uctm.edu/see/node/jsee2020-1/10_20-10_p_64-72.pdf

Laviosa, S., \& Cleverton, V. (2006). Learning by translating: A contrastive methodology for ESP learning and translation. Scripta Manent, 2(1), 3-12. Retrieved from http://www.sdutsj.edus.si/ScriptaManent/2006_1/Laviosa_Cleverton.pdf

Leonardi, V. (2009). Teaching business English through translation. Journal of Language \& Translation, 10(1), 139-153.

Lerga, M., \& Aibar, E. (2015). Best practice guide to use Wikipedia in university education. Retrieved from http://openaccess.uoc.edu/webapps/o2/bitstream/10609/41662/6/Best_Practice_ Guide_Wikipedia_2015.pdf

Lim, S. (2009). How and why do college students use Wikipedia? Journal of the American Society for Information Science and Technology, 60(11), 2189-2222. https://doi.org/10.1002/asi.21142

Mahmoud, A. (2006). Translation and foreign language reading comprehension: A neglected didactic procedure. English Teaching Forum, 44(4), 28-40. Retrieved from https://files.eric.ed.gov/fulltext/EJ1107902.pdf

Mažeikienè, V. (2018). Translation as a method in teaching ESP: An inductive thematic analysis of literature. Journal of Teaching English for Specific and Academic Purposes, 6(3), 513-523. https://doi.org/10.22190/JTESAP1803513M

Marinov, S. (2016). Translation exercise aided by data-driven learning in ESP sontext. ESP Today, 4(2), 225-250. https://doi.org/10.18485/esptoday.2016.4.2.5

Martínez Carrasco, R. (2018). Using Wikipedia as a classroom tool: A translation experience. In A. S. Albuquerque (Ed.), HEAD 2018 Proceedings: 4th International Conference on Higher Education Advances (pp. 909-916). Editorial Universitat Politècnica de València. https://doi.org/10.4995/HEAD18.2018.8112

McDonough Dolmaya, J. (2014). Revision history: Translation trends in Wikipedia. Translation Studies, 8(1), 16-34. https://doi.org/10.1080/14781700.2014.943279

McDonough Dolmaya, J. (2017). Expanding the sum of all human knowledge: Wikipedia, translation and linguistic justice. The Translator, 23(2), 143-157. https://doi.org/10.1080/13556509.2017.1321519

Moulton, M. R., \& Holmes, V. L. (2000). An ESL capstone course: Integrating research tools, techniques, and technology. TESOL Journal, 9(2), 23-29. Retrieved from https://eric.ed.gov/?id=EJ611411

Nikolić, J., Anđelković, J., \& Abramović, M. (2020). Gamified English language learning and teaching in a university context. In D. Starčević, \& S. Marinković (Eds.), Symorg 2020: Business and Artificial Intelligence: Symposium proceedings (pp. 94-101). Faculty of Organizational Sciences. Retrieved from http://symorg.fon.bg.ac.rs/wpcontent/uploads/2020/10/SYMORG-PROCEEDINGS-FINAL-2020.pdf

O’Brien, S. (2011). Collaborative translation. In Y. Gambier, \& L. van Doorslaer (Eds.), Handbook of translation studies: Volume 2 (pp. 17-20). John Benjamins Publishing Co.

Poonpon, K. (2017). Enhancing English skills through project-based learning. The English Teacher, $X L, 1-10$. Retrieved from https://www.researchgate.net/profile/KornwipaPoonpon/publication/324972858_Enhancing_English_skills_through_projectbased_learning/links/5bc2b20b458515a7a9e73088/Enhancing-English-skillsthrough-project-based-learning.pdf 
Prawat, R. S., \& Floden, R. E. (1994). Philosophical perspectives on constructivist views of learning. Educational Psychologist, 29(1), 37-48. https://doi.org/10.1207/s15326985ep2901_4

Simpson, J. (2011). Integrating project-based learning in an English language tourism classroom in a Thai university (Unpublished doctoral dissertation). Faculty of Education, Australian Catholic University, North Sydney, Australia. https://doi.org/10.4226/66/5a961e4ec686b

Stojković, N. (2021). Relevance of translation in ESP teaching methodology. Teme, XLV(1), 33-42. https://doi.org/10.22190/TEME200112003S

Stoller, F. (2002). Project work: A means to promote language and content. In J. C. Richards, \& W. A. Renandya (Eds.), Methodology in language teaching: An anthology of current practice (pp. 107-119). Cambridge University Press.

Stoller, F. (2006). Establishing a theoretical foundation for project-based learning in second and foreign language contexts. In G. H. Beckett, \& P. C. Miller (Eds.), Project-based second and foreign language education: Past, present, and future (pp. 19-40). Information Age Publishing.

Twomey Fosnot, C. (1989). Enquiring teachers, enquiring learners: A constructivist approach for teaching. Teachers College Press.

Vân Khánh, N. (2015). Towards improving ESP teaching/learning in Vietnam's higher education institutions: Integrating project-based learning into ESP courses. International Journal of Languages, Literature and Linguistics, 1(4), 227-232. Retrieved from http://www.ijlll.org/vol1/44-CL00006.pdf

Vygotsky, L. S. (1978). Mind in society. Harvard University Press.

JELENA ANĐELKOVIĆ, PhD, is an Assistant Professor at the Faculty of Organizational Sciences, University of Belgrade, where she is in charge of several courses in English for specific and academic purposes at undergraduate and master's level. Her academic and professional interests relate to the study of ESP and EAP, materials and curriculum design, corpus linguistics, and terminology language politics and planning.

MARIJA MERŠNIK, PhD candidate, is a Teaching Assistant at the Faculty of Organizational Sciences, University of Belgrade. Her main fields of interest include EAP, genre analysis, and materials and curriculum design. Together with colleagues from her Department, she has initiated a shift towards more innovative, technology driven and student-centered course syllabi.

JOVANA JOVIĆ, PhD candidate, is a Teaching Assistant at the Faculty of Organizational Sciences, University of Belgrade. Her research interests in the field of ESP center around mobile-assisted language learning (MALL). Another subject she finds particularly interesting is the comparison of programming language and natural language syntax. 


\section{Appendix A. PROJECT SURVEY}

\section{Section 1: General Information}

\section{Q1. Gender}

male / female

Q2. Study program
a) Management and Organization
b) Information Systems and Technologies

Q3. Grade Point Average
a) $6.00-6.99$
b) $7.00-7.99$
c) $8.00-8.99$
d) $9.00-9.99$
e) 10.00

Q4. Grade in ESP 1
a) 6
b) 7
c) 8
d) 9
e) 10
f) I haven't passed the exam yet

Q5. Grade in ESP 2
a) 6
b) 7
c) 8
d) 9
e) 10
f) I haven't passed the exam yet

Q6. I took part in the project as a:

a) translator

b) reviewer

Q7. There were students in my translation/revision team.
a) two
b) three
c) four
d) five
e) I was the only one

Section 2: Project work

Q8. Mark the following statements on a scale (1 - I completely disagree, 2 - I disagree, 3- I neither agree nor disagree, 4 - I agree, 5 - I completely agree, $X$ - N/A)

\begin{tabular}{|c|c|c|c|c|c|c|c|}
\hline No. & Statement & 1 & 2 & 3 & 4 & 5 & $\mathbf{X}$ \\
\hline 1 & The text for translation / revision was of adequate length. & & & & & & \\
\hline 2 & The text for translation / revision was of adequate complexity. & & & & & & \\
\hline 3 & $\begin{array}{l}\text { The seminar guidelines regarding translation helped me do the } \\
\text { task better and faster. }\end{array}$ & & & & & & \\
\hline
\end{tabular}




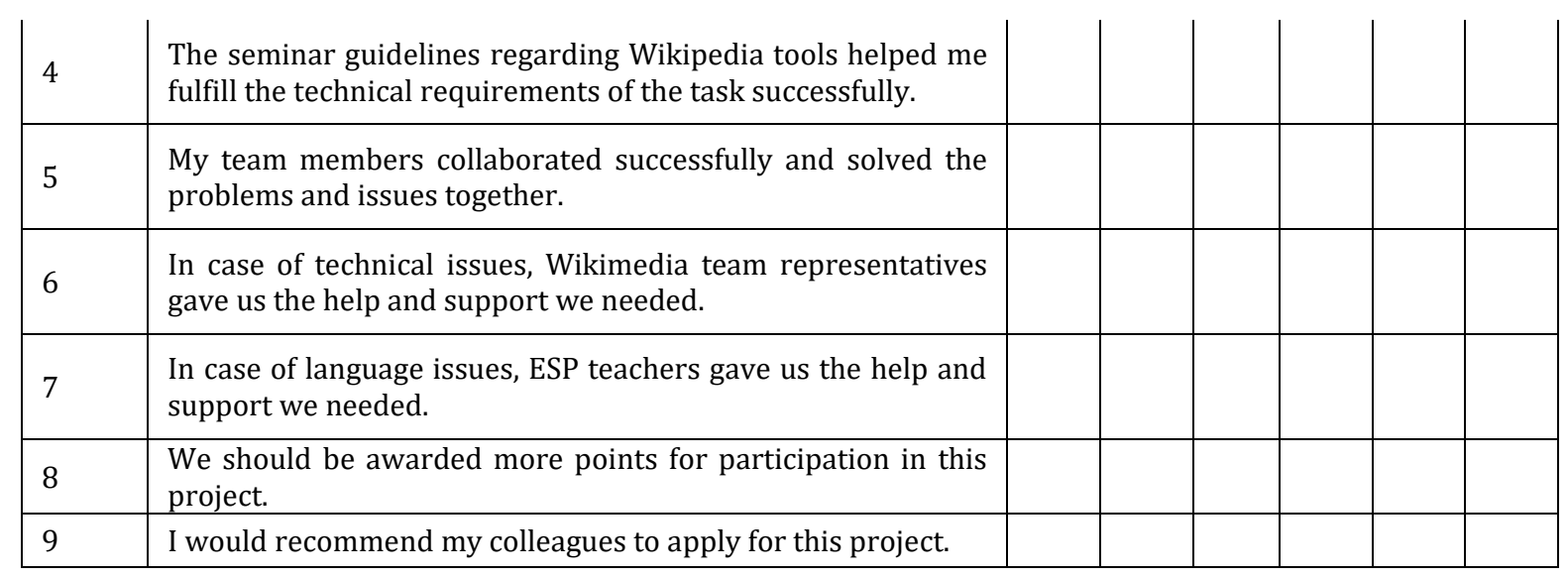

\section{Section 3: Project outcomes}

Q9. The greatest benefits the participation in the project brought me are:
a) I got a better grade in ESP2
b) I gained new knowledge and improved my skills
c) I improved my teamwork skills
d) I did not benefit from this project
e) Other:

Q10. Mark the following statements on a scale (1 - I completely disagree, 2 - I disagree, 3- I neither agree nor disagree, 4 - I agree, 5 - I completely agree, $X$ - N/A)

\begin{tabular}{|l|l|l|l|l|l|l|l|}
\hline No. & Statement & $\mathbf{1}$ & $\mathbf{2}$ & $\mathbf{3}$ & $\mathbf{4}$ & $\mathbf{5}$ & $\mathbf{X}$ \\
\hline 1 & $\begin{array}{l}\text { The project helped me improve my knowledge of } \\
\text { English for specific purposes and technical } \\
\text { terminology. }\end{array}$ & & & & & \\
\hline 2 & $\begin{array}{l}\text { The work on this project helped me become more } \\
\text { aware that I have gaps in my own knowledge of } \\
\text { my mother tongue. }\end{array}$ & & & & & & \\
\hline 3 & $\begin{array}{l}\text { I would like to get more specific feedback } \\
\text { regarding mistakes I made in translation / } \\
\text { revision. }\end{array}$ & & & & & \\
\hline 4 & $\begin{array}{l}\text { This kind of collaborative tasks contributes to } \\
\text { better acquisition of knowledge in particular } \\
\text { subject fields. }\end{array}$ & & & & & \\
\hline
\end{tabular}

Q11. Please share your comments and suggestions: 